\title{
Commercial Orientation and its Effects on Plant Diversity in Homegardens: An Empirical Investigation of Rural Households in Sri Lanka
}

\author{
Pradeepa Korale-Gedara $^{\dagger 1}$, Jeevika Weerahewa ${ }^{2}$, Gamini \\ Pushpakumara $^{3}$ and Sarath S. Kodithuwakku ${ }^{2,4}$
}

\begin{abstract}
It could be argued that commercially oriented famers pay more attention on reaping short term commercial benefits from their home-gardens and hence would not focus on longer term benefits that could be derived through enhanced biodiversity. Although empirical studies have been conducted to measure trade-offs between commercial orientation and plant diversity, hardly any research has carried out with the focus on homegardens in Sri Lanka. The main objective of this study is to explore the trade-offs between commercial orientation of farmers and plant diversity in homegardens in three districts in Sri Lanka, viz, Batticaloa Kandy and Kurunegala. The specific objectives are to $(i)$ measure the degree of plant diversity in home gardens, (ii) measure the degree of commercial orientation of farmers, and (iii) to econometrically estimate the relationship between plant diversity and commercial orientation of farmers. Data for this study were collected through a survey carried out in the three districts in 2009. Plant diversity was measured using three indices, namely Richness index, Shannon index and Simpson index and the degree of commercial orientation of farmers was measured using a number of proxies to capture the extent of market transactions and perceptions among farmers towards the purpose of farming. A set of multiple regression models were specified treating the level of commercialization, land size, employment status, education, household income and the geographical region as independent variables and plant diversity as the dependent variable. The results of the calculated indices revealed that homegardens in Kandy and Kurunegala districts are quite

\footnotetext{
${ }^{1} \mathrm{PhD}$ candidate, Department of Accounting, Finance and Economics, Griffith University, Gold Coast, Australia.

${ }^{2}$ Professor, Department of Agricultural Economics and Business Management, Faculty of Agriculture, University of Peradeniya, Sri Lanka.

${ }^{3}$ Professor, Department of Crop Science, Faculty of Agriculture, University of Peradeniya, Sri Lanka.

${ }^{4}$ Currently on leave serving at the Department of Natural Resource Economics, College of Agricultural and Marine Sciences, Sultan Qaboos University, Muscat, Oman as an Asst Professor.

${ }^{\dagger}$ Corresponding author, email: pradeepa.koralegedara@ griffithuni.edu.au
} 
diverse in plants and it is not that diverse in Batticaloa district. Approximately one half of the famers in Kandy and Kurunegala districts and four fifth of the farmers in Batticaloa are commercially oriented. The regression results showed that the farmers with commercial orientation tend to maintain home gardens with relatively higher plant diversity in Kandy district. However, commercial oriented farmers in Kurunegala district tend to maintain homegardens with less plant diversity compare to that of noncommercial oriented. The results also revealed that the plant diversity increases with the increase in land extent and 0.42 ha and 0.53 ha was estimated to be the land area which brings about the maximum plant richness in homegardens in Kandy and Kurunegala districts respectively.

\section{Introduction}

Homegardens are regarded as traditional multispecies agroforestry systems with a complex structure and multiple functions (Perera and Rajapakse, 1991; Hoogerbrugge and Fresco, 1993; Weerahewa et al., 2011). The role of homegardens is multi-faceted and most importantly they have the potential to ensure food needs of both rural and urban communities by providing a year-round source of nutritious food to households who may not otherwise have the access to such food (Torquebiau, 1992; FAO, 2010). Furthermore, they are identified as a sustainable and diverse agroforestry system that ensure conservation of a diversity of fruits, vegetables, spices and medicinal plants (Pushpakumara et al., 2010).

Literature reveals that high plant diversity found in Sri Lankan homegardens in the mid-country make them distinguishable from homegardens in South East Asia (Jacob and Alles, 1987). This feature found to be making them more similar to forests, though not identical (Wickramasinghe, 1995). High plant density is one of the salient characteristics of traditional homegardens which contributes largely towards making them sustainable agro ecosystem (Gajaseni and Gajaseni, 1999). They also help controlling the microclimate, regulating local hydrological process, protecting watershed and regulating undesirable organisms and detoxifying noxious chemicals and recycling nutrients more effectively (Kumari, 2009). According to Ariyadasa (2002) the average plant density of homegardens is about 200 trees per hectare and the highest in Sri Lanka has been recorded in Kegalle (475), followed by Matale (396).

Commercialization of agricultural systems has become inevitable, mainly due to population pressure and other related socioeconomic changes. Homegardens are no exception to this trend. Some ecologists are of the view that the commercialization of home gardens for gaining mere monetary 
benefits brings about adverse effects in terms of the sustainability of the system, particularly on its agrobiodiversity (Major et al., 2005). According to Abdoellah et al. (2006) efforts to encourage people to take into account their ecological role of homegardens in the cause of intensive agricultural development would not be an easy task, as the villagers are convinced that planting cash crops in homegarden is more profitable than conserving traditional homegardens which possess higher diversity of genetic resources.

An intensification of home gardens has been observed in the recent past in Sri Lanka so as to cope up with increasing food prices. This has also been promoted by the Sri Lankan government program (Ministry of Agricultural Development and Agrarian Services, 2010). It has been argued that such intensification may have eroded the plant diversity in homegardens.

The overall objective of this study is to examine whether there is a trade-off between plant diversity in the home garden and the degree of commercial orientation among the farming households. The specific objectives are to (i) measure the degree of plant diversity in homegardens, (ii) measure the degree of commercial orientation of farmers and (iii) to econometrically estimate the relationship between plant diversity and commercial orientation of homegardens in three districts in Sri Lanka.

The paper is organized as follows. The next section of the paper summarizes the findings of previous studies on determinants of plant diversity focusing on socio-economic aspects. The subsequent section of the paper shows the indices used for measuring plant diversity, the degree of commercial orientation and the econometric models specified. The section on the finding of the analysis is followed by the conclusions of the study.

\section{Socio-economic Determinants of Plant Diversity: A Review of Past Studies}

Factors that determined the plant diversity and the composition of plant species in a home-garden can be classified into three groups viz., (a) natural environmental factors such as climate, soil type, topography and relative humidity (Soemarwoto, 1987; Kumari, 2009), (b) socio-economic characteristics of the household (Kehlenbeck and Maass, 2004), and (c) characteristics of homegardens such as the type of tree crops available in the home-garden, location (i.e. urban/rural), and the size of the home-garden (Kehlenbeck et al., 2007; Wiehle et al., 2011). The degree of commercial orientation, i.e. the focus of the present study, can be considered as one of the key socio-economic characteristics which determine the degree of plant diversity in homegardens. 
Commercial orientation of farmers and plant diversity in homegarden: With the commercialization of agriculture it is expected that farmers tend to restructure their home-gardens to generate more monetary benefits. Such strategies may include devoting more land area for cash crops and replacing traditional non-commercial vegetables with cash crops (Soemarwoto and Conway, 1992), which may eventually result in displacement of many indigenous crops (Kumari, 2009). It has been found in Indonesia that commercialization of home gardens has enabled households to increase their incomes, although the same phenomenon has contributed towards reducing plant diversity, increases instability and social inequity (Abdoellah et al., 2006). Abdoellah et al. (2002) argue that treating homegarden as a stable method of in-situ conservation has become more challenging with the changes that have occurred in socio economic and cultural factors. In such a context, it could be argued that commercialization leads to the depletion of plant diversity in sustainable traditional agro-forestry systems. Consistent with this, a negative relationship between degree of market orientation and plant diversity was found in urban and peri-urban homegardens in Niger (Bernholt et al., 2009) and (Major et al., 2005) have found that though species richness on the farms has not been significantly influenced by market orientation of farmers, low-market orientated groups possess homegardens with high plant diversities compare to that of high market oriented groups. The same authors have concluded that commercialized homegardens can maintain species diversity with increased dominance of highly marketable species. Contradictory to this, Wiehle et al., 2005, has found a positive relationship between market orientation and species richness in homegardens in Nuba Mountains in Sudan.

Size of the home-garden: The relationship between plant diversity and size of the home garden is expected to be quadratic, i.e., plant diversity initially increases with the size of home garden, next reaches a maximum and finally declines. The positive relationship between homegarden size and plant diversity has been reinforced in many studies (Winters et al., 2006; Wiehle et al., 2011; Perrault-Archambault and Coomes, 2008). Pandy et al. (2006) has observed the opposite. Abede (2005) on the other hand, has argued that there is no relationship between either species richness and the farm size or species evenness and farm size.

Access to market: Access to road and involvement in off farm activities also found to be influencing the plant diversity. Kumari (2009) and Abede (2005) have argued that distance to market negatively influence the plant diversity. When farmers have easy access to market they tend to grow more of a limited number of cash crops instead of planting many varieties in the homegarden. 
Other factors: homegarden caretaker's habit to exchange the planting material among others in the community positively relates with the plant diversity (Lerch, 1999; Ban and Coomes, 2004). The gender of the care taker also affects on the plant diversity of homegarens, usually homegardens which are maintained by women tend to have a higher plant diversity (PerraultArchambault and Coomes, 2008).

Household Income: Relationship between biodiversity and household income is hypothesized to be positive as richer households tend to grow more crop varieties than poor households whose livelihood depends on return from farms (Mmom, 2009). Winters et al. (2006) argue that the richer households may have a greater capacity to access the seeds for these crops. Abede (2005) found that richness is positively related with household income, evenness of species is low in homegarden owned by rich household compared to that of poorer households. Kumari (2009) has argued that the higher the household expenses, the higher the food plant density and the lower the total plant diversity. The same author has observed that rich households in urban areas tend to plant more ornamental plants with higher economic values in their home gardens (Kumari, 2009).

Labour endowment: Winters et al. (2006) have found that labour endowment is negatively related with the plant diversity. In contrast, Abede (2005) has found that households with more family labour tend to have higher plant diversity, but with less evenness.

Age and education: According to Abede (2005) age, education and gender of the farmer do not have any effect on the plant density. Winters $e t$ al. (2006) argue that the educated people tend to plant crop species evenly in the home-gardens.

Family size and family structure: Abede (2005) has argued that family size affects only on the relative evenness of the number of functional groups of crops. Winters et al. (2006) have observed that plant diversity decreases with the increased dependency ratio (ratio of dependent to the adult labour) as households with more dependents compel to grow more of certain food items in their home gardens (Winters et al., 2006).

Natural environmental factors: Among the natural agro ecological factors that affects on the plant growth, slope, altitude and texture of the land influence on the plant diversity and evenness. With the large variation in slope and the texture of plant there is a high plant density and with the increase in slope evenness of plant species increase, while for the altitude it is other way round (Abede, 2005; Winters et al., 2006). 


\section{Methods of Analysis}

\section{Measurement of plant diversity}

Richness and evenness are the two aspects of plant diversity in a system. Richness expresses the total number of different species found in a given system whereas the relative abundance of plant species is explained by the term evenness (Olszewski, 2004). Although there are numerous indices that are used to measure the plant diversity, this study uses three indices which are extensively found in literature: Richness index, Shannon index and Simpson's index (Yue et al., 2004).

Richness Index is the count of the total number of crops that the household reports planting over the season of interest. However, this index does not indicate the relative proportion or abundance of a particular species in the farm.

Shannon index (I) expresses the proportional abundance or evenness, accounting for the land shares allocated to each crop as well as the number of crops. The Shannon index is higher when the relative abundance of the different species in the sample is even, and is low when few species are more abundant than the others.

$$
I=-\sum_{i=1}^{m(\varepsilon)} P_{i} \ln P_{i}
$$

$I \quad=$ Shannon Index

$P i \quad=$ Probability of the $i$ th species

$m(\in)=$ Total number of species

Simpson index $(S)$ provides the probability that two randomly selected plants belong to the same species. When this probability is high, diversity is low (Yue et al., 2004). The value of Simpson index ranges from 0 to 1 . While values closer to zero denote high diversity in the homegarden, value of 1 reflects monocroping (Canadian Forest Products Ltd, 2003).

$$
S=\sum_{i=1}^{m(\varepsilon)} P_{i}^{2}
$$

$S=$ Simpson index

$P i=$ Probability of the $i$ th investigation object such as species 


\section{Measurement of commercial orientation}

Commercialization does not only mean the marketing of output (Balint, 2003), but also it means the whole process of production that is oriented towards the market (i.e., integration of production and marketing decisions). Commercial orientation of farmers is visible even at the stage of selecting the crops to be planted and the type of inputs they use in producing these plants. In this study, commercial orientation of home-garden is primarily measured using the percentage of output sold in the market. The homegardens were grouped into four categories based on the percentage of the total harvest sold in the market, viz: subsistence (no harvest is marketed), less commercialized (zero to $25 \%$ is marketed), moderately commercialized (26\% to $75 \%$ is marketed) and highly commercialized (above $75 \%$ is marketed). This categorization was done with the purpose of analyzing the socio-economic and management practices related to level of commercialization and in the regression analysis, the percentage of total output sold in the market was included as a continuous variable.

The following proxies have also been used in the regression analysis to measure the degree of commercialization: (a) whether they use hired labor for home garden activities, and (b) whether they use fertilizer for homegarden activities.

\section{Assessment of the causality between the plant diversity and commercial orientation}

The following econometric model was specified to establish the causal relationship between the plant diversity and the degree of commercial orientation.

$$
I=I\left(X_{1}, X_{2}, X_{3}\right)
$$

Where,

$I_{i} \quad=\quad$ Plant diversity of the homegarden

$X_{1}=\quad$ Vector of Socio-economic characteristics of the household

$X_{2}=\quad$ Vector of Characteristics of the homegarden

$X_{3}=\quad$ Vector of Natural environmental factors

Three regression equations were specified treating the three plant diversity indices as dependent variables and were estimated using Ordinary Least Square (OLS) estimation with corrections for heteroskedasticity. 
Commercial orientation of the farmers was included in the regression models using alternative proxies as mentioned in the previous section.

\section{Data}

Data for the analysis was gathered from a survey carried out in three districts in Sri Lanka, viz, Batticaloa, Kandy and Kurunegala. These three districts represent three agro ecological zones of Sri Lanka, Dry Zone, Wet Zone and Intermediate zone respectively and hence the study covered three different agricultural systems in Sri Lanka. In each district, three divisional secretariat (DS) divisions were selected for the sample. Yatinuwara, Udunuwara and Kundasale from Kandy district, Kurunegala, Pannila and Ridiyagama from Kurunegala district and Manmunai south and eruvilpattu, Eravurpattu and Korelapattu from Batticaloa district were included. Total of 633 homegardens representing all three districts 218 from Kandy 219 from Kurunegala and 206 from Batticaloa were visited for the purpose of data collection during the periods from November 2009 to April 2010. A structured questionnaire was used to gather data.

The home gardens were selected based on the definition and key characteristics provided in the Agriculture Census of the Department of Census and Statistics (2002) which is as follows. A piece of land which has a dwelling house and having some form of cultivation was defined to be a homegarden, if the total area of that piece of land is twenty or less than twenty perches. Further, total area of which is more than twenty perches was also considered as home garden, if it has a dwelling house and the produce of the cultivated land is largely for home consumption. "Having some form of cultivation" was meant any cultivation for agriculture production. This will include even one coconut palm or one arecanut tree or couple of chili plants and it was treated as home garden, if the above conditions are satisfied. In this study, an upper limit on the land size was not considered.

\section{Results}

\section{The Sample Revisited: Socio-economic Characteristics of the Respondent}

Kandy district: An average household consists of 3 members, spending around 6 hours per week in the home garden-the average size of which is about 0.14 ha (i.e. 57.1 perches). The mean monthly income of household is Rs. 19,712 (which ranges from Rs. 3,515 to 100,000). The majority (52.29\%) of the respondents found to be paid employees (i.e. both in the government and private sectors) whereas about $17.43 \%$ are self employed. Only $2.75 \%$ of the respondents found to be fulltime 
farmers and about $28 \%$ of the respondents found to be not engaged in any formal employment (Table 1).

Table 1: $\quad$ Socio-economic characteristics of the households in Kandy, Kurunegala and Batticaloa districts

\begin{tabular}{|c|c|c|c|c|c|c|}
\hline $\begin{array}{c}\text { Selected } \\
\text { Characteristics }\end{array}$ & $\begin{array}{c}\text { Observed } \\
\text { Range }\end{array}$ & Categories & Count & Frequency & Mean & $\begin{array}{r}\text { Standard } \\
\text { Deviation }\end{array}$ \\
\hline \multicolumn{7}{|l|}{ Kandy District } \\
\hline Age & $24-77$ & & & & $\begin{array}{l}47.47 \\
\text { Years }\end{array}$ & 11.46 \\
\hline Employment & & $\begin{array}{l}\text { Regular work } \\
\text { Self employed } \\
\text { Farming } \\
\text { Unemployed }\end{array}$ & $\begin{array}{r}114 \\
38 \\
6 \\
60\end{array}$ & $\begin{array}{r}52.29 \% \\
17.43 \% \\
2.75 \% \\
27.52 \%\end{array}$ & & \\
\hline $\begin{array}{l}\text { Household size } \\
\text { Dependency ratio }\end{array}$ & $\begin{array}{c}1-9 \\
0-0.75\end{array}$ & & & & 3.17 & 1.34 \\
\hline $\begin{array}{l}\text { Total household } \\
\text { income } \\
\text { (Rs./month) }\end{array}$ & $\begin{array}{c}3000- \\
100000\end{array}$ & $\begin{array}{l}\text { Low }(3,000- \\
15,000) \\
\text { Middle }(15,000- \\
30,000)\end{array}$ & $\begin{array}{l}93 \\
93\end{array}$ & $\begin{array}{l}38.43 \\
38.43\end{array}$ & $19,712.62$ & $12,909.68$ \\
\hline (Rs./month) & & $\begin{array}{l}\text { High (more than } \\
30,000)\end{array}$ & 56 & 23.14 & & \\
\hline $\begin{array}{l}\text { Total labor hours } \\
\text { per week spending } \\
\text { in the home-garden }\end{array}$ & $0-76$ & & & & $\begin{array}{r}6.95 \text { hours } \\
\text { per week }\end{array}$ & 9.73 \\
\hline \multicolumn{7}{|l|}{ Kurunegala } \\
\hline Home-garden size & $\begin{array}{l}10-320 \\
\text { Perch }\end{array}$ & & & & $\begin{array}{l}57.51 \\
\text { Perch }\end{array}$ & 59.62 \\
\hline Age & $25-78$ & & & & $\begin{array}{l}49.29 \\
\text { Years }\end{array}$ & 12.661 \\
\hline Employment & & $\begin{array}{l}\text { Regular work } \\
\text { Farming } \\
\text { Unemployed }\end{array}$ & $\begin{array}{l}158 \\
15 \\
46\end{array}$ & $\begin{array}{l}72.15 \% \\
6.80 \% \\
21.20 \%\end{array}$ & & \\
\hline $\begin{array}{l}\text { Household size } \\
\text { Dependency ratio }\end{array}$ & $\begin{array}{c}1-9 \\
0-0.75\end{array}$ & $\begin{array}{l}\mathrm{NR} \\
\mathrm{NR}\end{array}$ & & & 4.10 & 1.442 \\
\hline \multirow{3}{*}{$\begin{array}{l}\text { Total household } \\
\text { income } \\
\text { (Rs./month) }\end{array}$} & $\begin{array}{l}2000- \\
80000\end{array}$ & $\begin{array}{l}\text { Low }(2,000- \\
15,000)\end{array}$ & 60 & 31.58 & $22,280.00$ & 13922.71 \\
\hline & & $\begin{array}{l}\text { Middle }(15,000- \\
30,000)\end{array}$ & 90 & 47.37 & & \\
\hline & & $\begin{array}{l}\text { High (more than } \\
30,000 \text { ) }\end{array}$ & 40 & 21.05 & & \\
\hline $\begin{array}{l}\text { Total labor hours } \\
\text { per week spending } \\
\text { in the home-garden }\end{array}$ & $0.5-52 \mathrm{hr}$ & & & & $\begin{array}{r}12.57 \\
\text { hours per } \\
\text { week }\end{array}$ & 9.26361 \\
\hline Home-garden size & $\begin{array}{l}20-640 \\
\text { Perch }\end{array}$ & & & & $\begin{array}{r}108.27 \\
\text { Perch }\end{array}$ & 109.12 \\
\hline
\end{tabular}




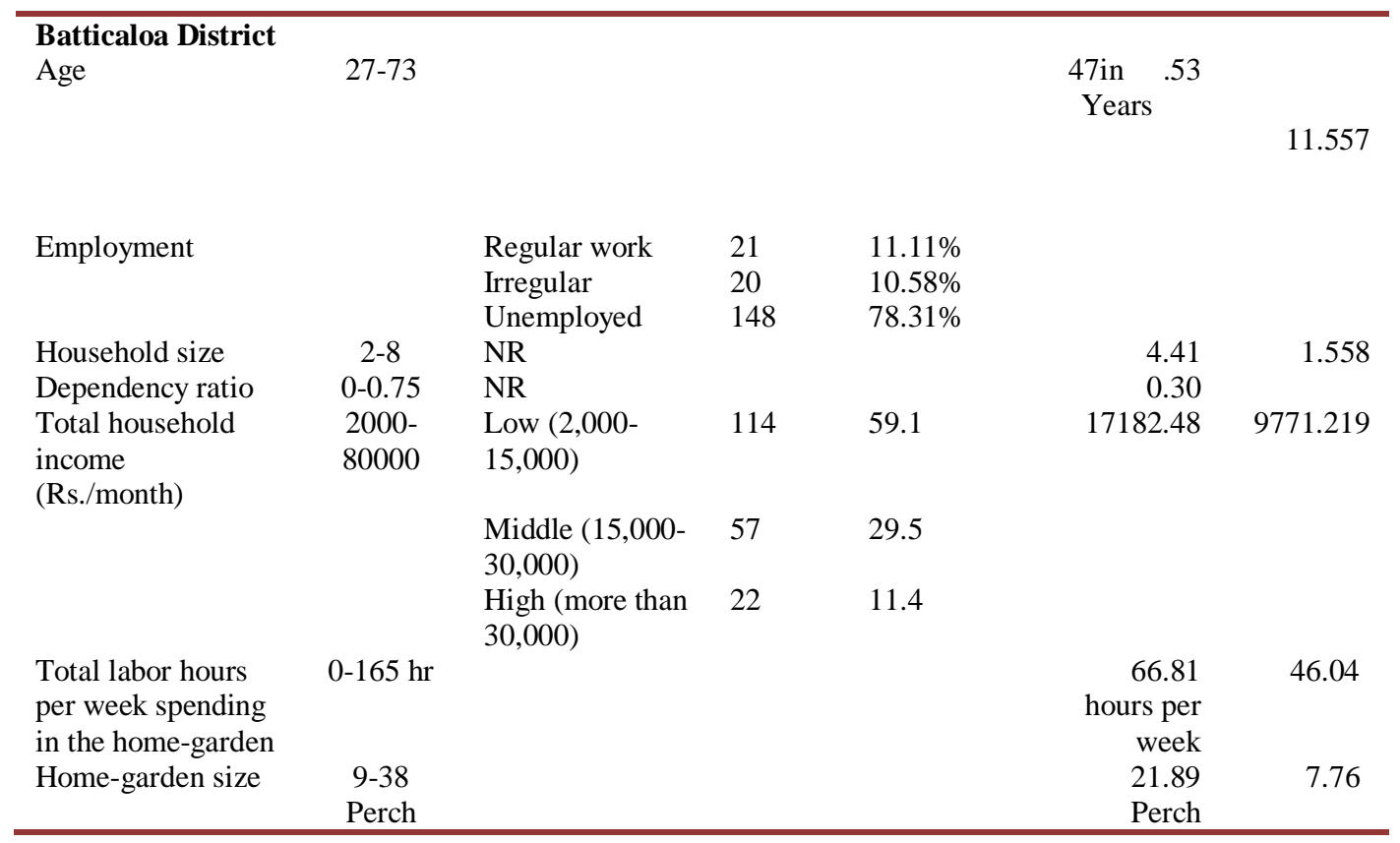

Kurunegala district: The socio economic profile in Kurunegala is not that different from Kandy district. The households in Kurunegala district spend double the time (12.57 hours/week) in homegardening and the home garden about 0.27 ha (i.e. 108.27 perches) in size. The mean monthly income of household is Rs. 22,280. The majority $(72.15 \%)$ of the respondents found to be paid employees (i.e. both in the government and private sectors) whereas about $6.80 \%$ are farmers. Only $21.2 \%$ of the respondents found to be not engaged in any formal employment (Table 1).

Batticaloa district: Compared to other two districts, the homegardens are small in Batticaloa district, the average size being about 0.06 ha (21.89 perches). The other main feature which distinguish Batticaloa district from others is that the majority $(78.31 \%)$ of the respondents found to be unemployed. There is a notable difference in Batticaloa district in terms of the monthly income level as well. The mean monthly income of household is Rs. 17,182.48 (which ranges from Rs. 1,500 to 40,000). Compared to the other two districts, majority (around 60\%) of the households fall under the category of low income group, while only a small percentage (11.11\%) engage in regular work, such as government and private sector jobs. As most of them are unemployed, the time spent in the homegarden per week is also as high as 66. 81 hours per week. 


\section{Commercial orientation of the farmers}

\section{Composition of the homegarden}

It was clear from the findings that the commercial orientation of farmers is mainly centred on the type of crops they grow in their home garden. The type of crops, number of crops which is marketed is directly influenced by the district in which the homegarden is located. In terms of the number of crops which is marketed by a household, relative to the other districts, homegardens in Kandy district produce a higher number of marketable crops. In consistence with the relative low plant diversity in Batticaloa district, the number of crops marketed is also limited to one to three crops. Despite that the mixture of marketable crop in each district is different from each other; it was revealed that banana and coconut were common in all three districts.

Kandy District: It was found that the commercial orientation of farmers was cantered on the types of crops they cultivated. Most of the vegetables and fruits which are grown in homegardens are used for homeconsumptions, such as Kochchi, (bird chili) Spinach, Drumstick, Brinjal, Guava, and Kiri ala (Milk yam). Though some of these crops are grown in many home-gardens they are rarely marketed. The salient feature of commercial orientation of households in Kandy district is that, most of the homegarden owners engage in selling spicy crops such as pepper, nutmeg, clove, coffee, and avocado, i.e. eight in ten households who are receiving a clove harvest sell their products while more than half of the households who cultivate pepper markets it. Can the botanical names, at least at species level for some provided?

It was evident that households grew certain crops solely for the purposes of selling and certain other crops for home consumption. For instance, arecanut, avocado, banana, clove, coconut, coffee, cocoa, ginger, and nutmeg are primarily grown for sale. Nearly almost all the respondents indicated that the entire harvest of arecanut, banana, ginger and nut-meg is sold. The harvests of the rest of the annual and perennial crops are used mainly for home consumption and the surplus is often shared with neighbors.

Kurunegala District: Compared to the Kandy district a very small number of products in homegardens in Kurunegala district is marketed. Among them, coconut and banana leads all the other crops. As findings revealed, $41 \%$ and $43 \%$ of households of those who harvest coconut and arecanut in Kurunegala district respectively engage in selling coconut and arecanut. Other than these two products, betel, mango, cashew, king coconut, 
orange and pepper is marketed. The significant feature of these products is that all most $80 \%$ of the harvest is being marketed i.e. $98 \%$ of the betel harvest is marketed. Thus, it can be concluded that these crops are grown in home-garden to market. In addition to this, crops like Papaw, Pineapple and lime are also marketed in small quantities.

Batticaloa District: As the diversity of crops in the home-gardens in Batticaloa is very limited (total of 25 crops), the number of products marketed from a home-garden is also very low. i.e. $97.9 \%$ of the home-gardern produce either three or less than three crops.

Almost all the households (93\%) who harvest banana sell their product. On average $80 \%$ of the harvest is sold. Coconut is the next commercial crop in Batticaloa. Around $73 \%$ of the home-gardens which harvests coconut sell it. Other than these two crops 24 households out of 26 households that harvest cashew, market the harvest. Anoda, (a fruit) brinjal, guava, jack fruit, mango and okra are among the other crops which are marketed in small quantities.

\section{Degree of commercial orientation}

As indicated earlier, the homegardens were grouped into four categories based on the percentage of the total harvest sold in the market, viz: subsistence, less commercialized, moderately commercialized and highly commercialized. The Table 2 explains the situation in each three district.

Table 2: $\quad$ Levels of commercial orientation

\begin{tabular}{lccc}
\hline \multirow{2}{*}{$\begin{array}{c}\text { Level of } \\
\text { commercialization }\end{array}$} & \multicolumn{3}{c}{ Percentage of homegardens in each category } \\
\cline { 2 - 4 } & Kandy & Kurunegala & Batticaloa \\
\cline { 2 - 4 } & $44.03 \%$ & $40.55 \%$ & $14.0 \%$ \\
\hline Subsistence level & $4.58 \%$ & $39.17 \%$ & $44.0 \%$ \\
Less commercialized & $8.25 \%$ & $18.89 \%$ & $25.4 \%$ \\
Moderately & & & \\
commercialized & $43.12 \%$ & $1.38 \%$ & $16.6 \%$ \\
Highly & & & \\
commercialized & & & \\
\hline
\end{tabular}

As per the table revealed, the distributions of home-gardens that are at different levels of commercial orientation are very much different from each other in three districts. Relative to Kandy districts, in other two districts most of the home-gardens are managed as either less commercialized or moderately 
commercialized home-gardens while they are managed either as subsistence or highly commercialized in Kandy district.

Further analysis revealed that assistance of hired labour was sought only by $14 \%, 20.3 \%$ and $22.3 \%$ of households in Kandy, Kurunegala and Batticaloa districts respectively, mainly for planting and harvesting purposes whereas application of fertilizer is recorded only among 22\%, 52.8\% and $51.9 \%$ of the respondents in respective three districts. This clearly indicates that the use of external inputs to the homegarden is comparatively low in Kandy district, especially in terms of fertilizer application. This might be basically due to the type of crops they are growing in their homegardens and the nutrient status of the soil.

Table 3 shows the extent to which the usage of inputs is associated with the degree of commercial orientation as classified using the percentage of output sold. Interestingly, the lowest rates of external inputs usage were recorded in subsistence farmers except fertilizer usage in Batticaloa district. Though there is no clear pattern observed among groups at different commercial orientation groups, it was observed that the labour usage is increasing with the level of commercial orientation in Kurunegala district.

Table 3: $\quad$ Usage of external inputs in the homegarden

\begin{tabular}{lrrrrrr}
\hline \multirow{2}{*}{$\begin{array}{c}\text { Level of } \\
\text { Commercialization }\end{array}$} & \multicolumn{3}{c}{$\begin{array}{c}\text { Percentage of Households those } \\
\text { Who Hire Labour }\end{array}$} & \multicolumn{3}{c}{$\begin{array}{c}\text { Percentage of Households Who Use } \\
\text { Fertilizer }\end{array}$} \\
\cline { 2 - 7 } & Kandy & \multicolumn{1}{c}{ Kurunegala } & \multicolumn{1}{c}{ Batticaloa } & Kandy & Kurunegala & Batticaloa \\
\hline Subsistence level & 6.25 & 25.00 & 20.00 & 18.89 & 43.18 & 70.37 \\
$\begin{array}{l}\text { Less commercialized } \\
\text { Moderately }\end{array}$ & 10.00 & 17.86 & 21.69 & 50.00 & 58.02 & 54.12 \\
$\begin{array}{l}\text { commercialized } \\
\text { Highly }\end{array}$ & 27.78 & 10.00 & 26.53 & 37.50 & 62.05 & 44.90 \\
commercialized & 20.43 & 33.33 & 21.88 & 22.09 & 66.67 & 40.63 \\
\hline
\end{tabular}

\section{Income and the level of commercialization}

Only smaller percentages of high income category respondents were found among highly commercialized and moderately commercialized farmers. On the other hand it was found that most of the less commercialized homegardens are managed by households in high income groups. Moreover, it is quite evident that a larger majority of moderately commercialized farmers belong to the Low income group (Table 4).

As the Table 5 illustrates, the tendency of the farmers to be commercially oriented found to be increasing with the increase of land size, except for the Kandy district highly commercialized category, which showed 
a slightly low value compare to moderately commercialized homegardens.

The same trend is observed with respect to labour usage (Table 5).

Table 4: $\quad$ Income category and level of commercialization

\begin{tabular}{|c|c|c|c|c|c|c|c|c|c|}
\hline & \multicolumn{3}{|c|}{$\begin{array}{c}\text { Low Income Group } \\
3,000-15,000\end{array}$} & \multicolumn{3}{|c|}{$\begin{array}{c}\text { Middle Income Group } \\
15,000-30,000\end{array}$} & \multicolumn{3}{|c|}{$\begin{array}{c}\text { High Income Group } \\
>\mathbf{3 0 , 0 0 0}\end{array}$} \\
\hline & Kandy & Kurunegala & Batticaloa & Kandy & Kurunegala & Batticaloa & Kandy & Kurunegala & Batticaloa \\
\hline Subsistence level & 45.83 & 23.29 & 51.85 & 42.71 & 50.68 & 29.63 & 11.46 & 26.03 & 18.52 \\
\hline $\begin{array}{l}\text { Less } \\
\text { commercialized }\end{array}$ & 30.00 & 28.38 & 58.82 & 40.00 & 50.00 & 30.59 & 30.00 & 21.62 & 10.59 \\
\hline $\begin{array}{l}\text { Moderately } \\
\text { commercialized }\end{array}$ & 41.18 & 51.28 & 65.31 & 52.94 & 35.90 & 26.53 & 5.88 & 12.82 & 8.16 \\
\hline $\begin{array}{l}\text { Highly } \\
\text { commercialized }\end{array}$ & 42.86 & 33.33 & 56.25 & 42.86 & 66.67 & 31.25 & 14.29 & 0.00 & 12.50 \\
\hline
\end{tabular}

Table 5: $\quad$ Commercial orientation vs. key socio-economic characteristics of homegarden

\begin{tabular}{|c|c|c|c|c|c|c|c|c|c|}
\hline \multirow[t]{2}{*}{$\begin{array}{l}\text { Level of } \\
\text { commercialization }\end{array}$} & \multicolumn{3}{|c|}{ Land Size (ha) } & \multicolumn{3}{|c|}{$\begin{array}{c}\text { Total Labour-hours Spend in the Home- } \\
\text { garden }\end{array}$} & \multicolumn{3}{|c|}{ Income } \\
\hline & Kandy & Kurunegala & Batticaloa & Kandy & Kurunegala & Batticaloa & Kandy & Kurunegala & Batticaloa \\
\hline Subsistence & 0.115 & 0.234 & 0.057 & 5.1 & 9.82 & 68.37 & 19,025 & 25,006 & 20,351 \\
\hline Less commercialized & 0.130 & 0.330 & 0.051 & 5.9 & 13.71 & 69.21 & 27,201 & 22,324 & 17,529 \\
\hline $\begin{array}{l}\text { Moderately } \\
\text { commercialized }\end{array}$ & 0.193 & 0.361 & 0.058 & 11.3 & 13.95 & 65.14 & 18,809 & 18,282 & 16,612 \\
\hline $\begin{array}{l}\text { Highly } \\
\text { commercialized }\end{array}$ & 0.168 & 1.219 & 0.060 & 8.12 & 23.00 & 65.53 & 21,765 & 19,000 & 18,046 \\
\hline
\end{tabular}

\section{Plant diversity in the homegardens}

There are around 200 plant species in home-gardens in Kandy and Kurunegala district and the total number of plant species found in Batticaloa district is 25 . Although there are large number of plant species in the study areas in Kandy and Kurunegala, the number of plant species in a given homegarden ranged from1 to 52 in Kandy district and 1 to 38 in Kurunegala district, with 22 and 16 being the average in Kandy and Kurunegala respectively. Compare to the other two districts, total number of plant species found in the Batticaloa district is as low as 25 and the number of plant species found in a given home-garden ranged from zero to six (Table 6).

As far as the diversity of plants within each of the 5 functional plant groups are concerned, there found to be around 49, 30 and 12 food tree species in Kandy, Kurunegala and Batticaloa district respectively. Other than this 44, 40 and 7 fruit trees were found in the three studied areas. Furthermore, 32 and 20 timber plant species and 16 and 10 medicinal plants and 16 and 12 spicy crops and 9 ornamental plants were observed in Kandy and Kurunegala districts. 
Table 6: Descriptive statistics on plant diversity in home-gardens in studied areas

\begin{tabular}{lccc}
\hline Indicators & Kandy & Kurunegala & Batticaloa \\
\hline $\begin{array}{l}\text { Total number of plant } \\
\text { species }\end{array}$ & 206 & 210 & 25 \\
$\begin{array}{l}\text { Maximum number of plant } \\
\text { species in a home-garden }\end{array}$ & 52 & 38 & 6 \\
$\begin{array}{l}\text { Minimum number of plant } \\
\text { species in a home-garden }\end{array}$ & 1 & 5 & 0 \\
$\begin{array}{l}\text { Average number of plant } \\
\text { species in home-garden }\end{array}$ & 22 & 16 & 2 \\
\hline
\end{tabular}

Table 7 presents the richness and evenness of plants in different types of homegardens as measured by Richness, Shannon and Simpson indices by the level of commercial orientation.

It was found that the highest Richness value and lowest Simpson value was recorded in Kandy district while the lowest Richness and highest Simpson value was recorded in Batticaloa district. As higher Simpson value reflects less evenness in the home-garden, this implies that plant diversity in Kandy district is high and plants are evenly distributed and the plant diversity in Batticaloa district is low and distribution is closer to a mono cropping system (Simpson Value: 0.727).

Richness value comparison across different levels of commercialization shows that in Kurunegala and Batticaloa districts the lowest richness index value was recorded for highly commercialized homegardens and the value is highest for less commercialized home-gardens. Compared to these two districts, Kandy shows somewhat different pattern with respect to Richness and Simpson index. In Kandy district, among the subsistence, less commercialized and moderately commercialized farmers, less commercialized farmers possess home-gardens with the highest Richness index and Shannon index and Subsistence home-garden possess the lowest Simpson index.

One way Analysis of Variance (ANOVA) tests were performed to evaluate whether statistically significant differences exist in means of Richness, Shannon and Simpson index among commercialization categories. The results reveal that such differences are statistically significant only for the Richness index in Kandy district and for Shanon and Simipson index in Kurunegala districts. This indicates that there is a clear difference in plant richness among commercialized categories in Kandy district and the plant 
evenness of homegardens in Kurunegala district is different between different commercialized categories.

While mean comparisons, as performed above, indicate the association between plant diversity and the degree of commercialization, they cannot be utilized to infer the extent to which the degree of commercialization explains plant diversity while other factors affecting plant diversity are held at constant levels. The following section presents the results of a series of regression models estimated to investigate the relationship between plant diversity and the degree of commercialization (which can control for the other factors affecting the plant diversity).

Table 7: $\quad$ Relationship between plant diversity and degree of commercialization

\begin{tabular}{|c|c|c|c|c|c|c|c|c|c|}
\hline \multirow{3}{*}{$\begin{array}{c}\text { Level of } \\
\text { Commercial- } \\
\text { ization }\end{array}$} & \multicolumn{9}{|c|}{ Mean Value } \\
\hline & \multicolumn{3}{|c|}{ Kandy } & \multicolumn{3}{|c|}{ Kurunegala } & \multicolumn{3}{|c|}{ Batticaloa } \\
\hline & $\begin{array}{l}\text { Richness } \\
\text { Index }\end{array}$ & $\begin{array}{l}\text { Shannon } \\
\text { Index }\end{array}$ & $\begin{array}{l}\text { Simpson } \\
\text { Index }\end{array}$ & $\begin{array}{l}\text { Richness } \\
\text { Index }\end{array}$ & $\begin{array}{l}\text { Shannon } \\
\text { Index }\end{array}$ & $\begin{array}{l}\text { Simpson } \\
\text { Index }\end{array}$ & $\begin{array}{l}\text { Richness } \\
\text { Index }\end{array}$ & $\begin{array}{l}\text { Shannon } \\
\text { Index }\end{array}$ & $\begin{array}{l}\text { Simpson } \\
\text { Index }\end{array}$ \\
\hline All & $\begin{array}{c}21.98 \\
(8.24)\end{array}$ & $\begin{array}{c}2.505 \\
(0.49)\end{array}$ & $\begin{array}{c}0.1339 \\
(0.10)\end{array}$ & $\begin{array}{c}15.90 \\
(7.13)\end{array}$ & $\begin{array}{l}2.01 \\
(0.56)\end{array}$ & $\begin{array}{l}0.234 \\
(0.13)\end{array}$ & $\begin{array}{c}1.839 \\
(0.89)\end{array}$ & $\begin{array}{c}0.426 \\
(0.41)\end{array}$ & $\begin{array}{c}0.727 \\
(0.248)\end{array}$ \\
\hline Subsistence level & $\begin{array}{c}19.69 \\
(8.04)\end{array}$ & $\begin{array}{l}2.457 \\
(0.50)\end{array}$ & $\begin{array}{c}0.1326 \\
(0.10)\end{array}$ & $\begin{array}{c}14.79 \\
(6.72)\end{array}$ & $\begin{array}{c}2.074 \\
(0.59)\end{array}$ & $\begin{array}{r}0.2156 \\
(0.14)\end{array}$ & $\begin{array}{l}1.185 \\
(0.56)\end{array}$ & $\begin{array}{c}0.098 \\
(0.29)\end{array}$ & $\begin{array}{l}0.938 \\
(0.18)\end{array}$ \\
\hline $\begin{array}{l}\text { Less } \\
\text { commercialized }\end{array}$ & $\begin{array}{l}25.70 \\
(8.94)\end{array}$ & $\begin{array}{l}2.676 \\
(0.50)\end{array}$ & $\begin{array}{l}0.1196 \\
(0.09)\end{array}$ & $\begin{array}{c}17.47 \\
(7.35)\end{array}$ & $\begin{array}{c}2.086 \\
(0.53)\end{array}$ & $\begin{array}{l}0.2191 \\
(0.12)\end{array}$ & $\begin{array}{l}2.105 \\
(1.07)\end{array}$ & $\begin{array}{l}0.5316 \\
(0.451)\end{array}$ & $\begin{array}{c}0.673 \\
(0.289)\end{array}$ \\
\hline $\begin{array}{l}\text { Moderately } \\
\text { commercialized }\end{array}$ & $\begin{array}{c}26.33 \\
(8.00)\end{array}$ & $\begin{array}{l}2.727 \\
(0.37)\end{array}$ & $\begin{array}{l}0.1053 \\
(0.06)\end{array}$ & $\begin{array}{c}15.75 \\
(7.16)\end{array}$ & $\begin{array}{c}1.771 \\
(0.49)\end{array}$ & $\begin{array}{l}0.2947 \\
(0.15)\end{array}$ & $\begin{array}{c}2.081 \\
(0.49)\end{array}$ & $\begin{array}{l}0.593 \\
(0.25)\end{array}$ & $\begin{array}{l}0.598 \\
(0.15)\end{array}$ \\
\hline $\begin{array}{l}\text { Highly } \\
\text { commercialized }\end{array}$ & $\begin{array}{l}22.86 \\
(7.85)\end{array}$ & $\begin{array}{c}2.494 \\
(0.48)\end{array}$ & $\begin{array}{l}0.1402 \\
(0.12)\end{array}$ & $\begin{array}{c}12.33 \\
(4.72)\end{array}$ & $\begin{array}{c}1.357 \\
(0.44)\end{array}$ & $\begin{array}{l}0.3196 \\
(0.15)\end{array}$ & $\begin{array}{l}1.312 \\
(0.54)\end{array}$ & $\begin{array}{c}0.166 \\
(0.29)\end{array}$ & $\begin{array}{l}0.891 \\
(0.19)\end{array}$ \\
\hline
\end{tabular}

Note: Numbers in parenthesis show standard deviation

\section{Determinants of plant diversity in homegardens}

Table 8 and 9depict the results of selected estimations obtained through OLS regression models with corrections for heteroscedasticity. The goodness of fit values of the models range from $9 \%$ to $29 \%$ indicating that the set of independent variables used in the models are capable of explaining only a smaller fraction of the variability of plant richness and evenness. However, the results of the estimation are quite consistent across alternative specifications formulated by changing the indices used for plant diversity and commercial orientation. They show that size of the homegarden, total monthly income of the household, geographical location; employment type and degree of commercialization significantly influence plant richness and evenness in the homegarden.

Table 8 and 9 respectively show the results of estimations that treated Richness index as the dependent variable in Kandy and Kurunegala district 
respectively. The results reported in the first column treats the average share of output sold in the market as a proxy for commercial orientation. The coefficient of the said variable is positive and significant for Kandy district while it is negative and significant for Kurunegala district. Similar results were found when Shannon index is taken as the dependent variable (Column 2 of Table 8 and 9) suggesting that the higher the degree of commercialization, the higher the plant diversity is in Kandy district when the other variables affecting plant diversity are held at constant levels and it is quite opposite form the results reported for Kurunegala. Has no significance?

The results reported in the second columns of Tables 8 and 9 considers a number of variables, i.e., average share of output sold in the market, the number of items sold, and those who use purchased inputs (fertilizer and labour) as proxies for commercial orientation. Table 13 shows that the number of items sold in the market has a positive and statistically significant relationship with plant richness in Kandy district.

Other than the level of commercialization, the other most important variable which was found to be significant in the regression models is the land size. Land size is positively related to the plant richness both in Kandy and Kurunegala district. On the other hand, the negative sign for the square term of the land shows that though the plant richness increases with the increases in land size, there is a limit for this increase and after that particular maximum point the plant diversity of the homegarden tends to decline.

\section{Discussion}

In line with the hypothesis stated, the regression results prove that in Kurunegala district, higher the commercial orientation, higher the tendency for homegarden owners to allocate a larger extent of their home gardens for cash crops and lower the plant richness and evenness of the home garden. In contrast to this, commercially oriented farmers in Kandy district seem to possess richer and even homegardens compared to that of subsistence farmers, indicating that though homegardens are commercialized in Kandy district, still the diversity is high.

This finding in Kandy district, which is quite contrary to the findings of many previous studies and to the findings of the Kurunegala district, can be intuitively explained using a number of reasons, which are specific to the context examined. The farmers with a commercial orientation in this area make a conscious effort to increase the diversity in the homegarden as a strategy to increase their earnings from homegardens. In absence of well developed supply chains, most of the farmers have limited opportunities to 
sell the harvest of the tree crops in large quantities. Therefore, they rely on the local markets (village fairs, collectors etc.) to sell smaller quantities of large variety of products at different times of the year. As a result they end up with having homegardens that are diversified, with a capability of producing multiple crops/products in order to extract maximum values from the limited extent of lands available (note that spice crops and perennial trees relatively require a smaller land area in home-gardens compared to most of the annual crops). Such value extraction is done through capitalizing a larger number of minuscule multiple opportunities, that are spread across time. These findings are consistent with the claims made by Kodithuwakku and Rosa (2002) for resource poor farmers. Furthermore, the smaller land extents available in the area prevent farmers from adopting mono cropping as a strategy to enhance their earnings from farming.

On the other hand, in Kurunegala the main commercial crops are coconut and banana, which require more than one plant to be in the homegarden to get a marketable surplus. Thus, commercially oriented farmers in Kurunegala district have to devote a substantial area in their homegarden for these marketable crops if they want to get a surplus of harvest. This would be the reason that it was found there is a negative relationship between plant diversity and the level of commercial orientation in Kurunegala district.

The results consistently indicate that both plant richness and evenness increases with the increase in the home-garden size, then reaches a maximum and finally declines. In all the models estimated for plant richness, land variables (land size and square of land size) are found significant in both districts. The optimum land area which yields the maximum plant richness is estimated to be approximately 0.42 ha and 0.53 ha for Kandy and Kurunegala respectively.

The relationship between total household income and plant richness found to be positive and significant in the first model for Kandy district, suggesting that the high-income farmers are capable of maintaining species rich homegardens (Table 8). In contrast to this in Kurunegala district, it was found that people employed as regular workers and farmers tend to maintain diverse homegardens compared to that of unemployed people.

Moreover, it was found that there is a significant variation in terms of the plant diversity across three DS divisions. The results of the estimations show that in Kandy district home-gardens in Yatinuwara shows a lower plant richness compared to that of in Kundasale and in Kurunegala district. Kurunegala secretariat division shows a higher plant richness compares to Ridigama area. 


\section{Conclusions}

The overall objective of this study was to explore whether there is a relationship between plant diversity and level of commercial orientation of homegardens in three districts in Sri Lanka. The results revealed that plant diversity of homegardens in Kandy district is relatively high and the evenness and richness of homegardens found to be increasing as home garden operators become commercialized. Contrast to this though the plant diversity in Kurunegala district is also high, the richness and the evenness of the homegarden declines as homegardens become more commercialized. The results further indicate that the relationship between the size of the homegarden and plant diversity is inverted $\mathrm{U}$ shaped and the highest plant density is observed in home gardens with 0.42 ha in Kandy district and 0.53 ha in Kurunegala district.

Due to the main difference in agricultural systems in Kandy and Kurunegala districts, the direction of the relationship between plant diversity and commercial orientation in two districts is opposite to each other. Thus, it can be concluded that though homegardens are commercialized due to urbanization and promotion of intensive cultivations, it does not always reduce the plant diversity in the homegarden and this provides a great opportunity to increase the income derived from homegardens without eroding the diversity of the area under special conditions. 
Table 8: $\quad$ Determinants of plant diversity in home-gardens in Kandy district (Model 1, 2 and 3)

\begin{tabular}{|c|c|c|c|c|c|c|c|}
\hline \multirow[t]{2}{*}{ Independent Variables } & \multirow[t]{2}{*}{ Independent Variables } & \multicolumn{2}{|c|}{$\begin{array}{c}\text { Dependent Variable: Richness } \\
\text { Index (Model 1) }\end{array}$} & \multicolumn{2}{|c|}{$\begin{array}{c}\text { Dependent Variable: Shannon } \\
\text { Index (Model 2) }\end{array}$} & \multicolumn{2}{|c|}{$\begin{array}{c}\text { Dependent Variable: Simpson } \\
\text { Index (Model 3) }\end{array}$} \\
\hline & & $\begin{array}{l}\text { Output Based } \\
\text { Indices }\end{array}$ & $\begin{array}{l}\text { Combined } \\
\text { Indices }\end{array}$ & $\begin{array}{l}\text { Output based } \\
\text { Indices }\end{array}$ & $\begin{array}{l}\text { Combined } \\
\text { Indices }\end{array}$ & $\begin{array}{l}\text { Output Based } \\
\text { Indices }\end{array}$ & $\begin{array}{l}\text { Combined } \\
\text { Indices }\end{array}$ \\
\hline Dependency ratio & Unit less & & & $\begin{array}{l}-0.1927^{*} \\
(0.0924)\end{array}$ & & & \\
\hline Household size & Number of people in the household & $\begin{array}{l}-0.5545 \\
(0.5552)\end{array}$ & $\begin{array}{l}-0.5277 \\
(0.5840)\end{array}$ & $\begin{array}{c}0.0221 \\
(0.0355)\end{array}$ & $\begin{array}{c}-0.0017 \\
(0.0390)\end{array}$ & $\begin{array}{r}-0.00214 \\
(0.0074)\end{array}$ & $\begin{array}{l}-0.0019 \\
(0.0086)\end{array}$ \\
\hline Education & Number of years of schooling & $\begin{array}{l}-0.1818 \\
(0.2309)\end{array}$ & & & & & \\
\hline Labor availability & $\begin{array}{l}\text { Total labor hours available for home-garden } \\
\text { activities per week }\end{array}$ & & & $\begin{array}{c}0.0004 \\
(0.0050)\end{array}$ & & $\begin{array}{l}0.0006 \\
(0.0012)\end{array}$ & \\
\hline Total monthly income & Rupees & $\begin{array}{c}0.0001^{*} \\
(0.0000)\end{array}$ & $\begin{array}{r}0.00005 \\
(0.0000)\end{array}$ & $\begin{array}{l}1.13 \times 10^{-6} \\
\left(2.57 \times 10^{-6}\right)\end{array}$ & $\begin{array}{l}1.70 \times 10^{-6} \\
\left(2.51 \times 10^{-6}\right)\end{array}$ & $\begin{array}{l}-1.27 \times 10^{-7} \\
\left(5.07 \times 10^{-7}\right)\end{array}$ & $\begin{array}{l}-2.98 \times 10^{-8} \\
\left(4.90 \times 10^{-7}\right)\end{array}$ \\
\hline Land Size & Perch & $\begin{array}{l}0.1486^{* * *} \\
(0.0321)\end{array}$ & $\begin{array}{l}0.1395^{* * * *} \\
(0.0348)\end{array}$ & $\begin{array}{l}0.0076 * * * \\
(0.0002)\end{array}$ & $\begin{array}{l}0.0079^{* * * *} \\
(0.0019)\end{array}$ & $\begin{array}{l}-0.0013^{* * *} \\
(0.0004)\end{array}$ & $\begin{array}{l}-.0013 * * \\
(0.0004)\end{array}$ \\
\hline Land square & Square of land area & $\begin{array}{l}-0.0043^{* * *} \\
(0.000)\end{array}$ & $\begin{array}{l}-0.0041^{* * * *} \\
(0.0001)\end{array}$ & $\begin{array}{l}-0.00002^{*} \\
\left(6.67 \times 10^{-6}\right)\end{array}$ & $\begin{array}{l}-0.00002^{* * *} \\
\left(6.85 \times 10^{-6}\right)\end{array}$ & $\begin{array}{r}5.38 \times 10^{-6 * * *} \\
\left(1.36 \times 10^{-6)}\right.\end{array}$ & $\begin{array}{l}5.14-\times 10^{-6 * * *} \\
\left(1.45 \mathrm{e} \times 10^{-6}\right)\end{array}$ \\
\hline Regular work & Housework (0), Regular work (1) & $\begin{array}{l}-1.513 \\
(2.357)\end{array}$ & $\begin{array}{l}-0.5462 \\
(2.5484)\end{array}$ & $\begin{array}{l}-0.0439 \\
(0.1595)\end{array}$ & $\begin{array}{l}-0.0302 \\
(0.1708)\end{array}$ & $\begin{array}{l}0.0108 \\
(0.0301)\end{array}$ & $\begin{array}{c}0.0071 \\
(0.0297)\end{array}$ \\
\hline Irregular work & Housework (0), irregular work (1) & $\begin{array}{l}-2.2045 \\
(2.5366)\end{array}$ & $\begin{array}{l}-1.323 \\
(2.7269)\end{array}$ & $\begin{array}{l}-0.0939 \\
(0.1650)\end{array}$ & $\begin{array}{l}-0.0803 \\
(0.1775)\end{array}$ & $\begin{array}{l}0.0105 \\
(0.0278)\end{array}$ & $\begin{array}{c}0.0099 \\
(0.0298)\end{array}$ \\
\hline Farming & Housework (0), farming (1) & $\begin{array}{l}2.0198 \\
(7.385)\end{array}$ & $\begin{array}{c}3.4241 \\
(7.2744)\end{array}$ & $\begin{array}{l}-0.4450 \\
(0.3188)\end{array}$ & $\begin{array}{l}-0.3952 \\
(0.3167)\end{array}$ & $\begin{array}{l}0.0746 \\
(0.0586)\end{array}$ & $\begin{array}{c}0.0670 \\
(0.0564)\end{array}$ \\
\hline \multirow[t]{4}{*}{ Commercial orientation } & Percentage of output sold to outside markets & $\begin{array}{c}3.043^{*} \\
(1.2650)\end{array}$ & & $\begin{array}{l}0.1073^{* *} \\
(0.0835)\end{array}$ & & $\begin{array}{l}-0.0134 \\
(0.0182)\end{array}$ & \\
\hline & Number of products marketed & & $\begin{array}{l}1.1608^{* *} \\
(0.4222)\end{array}$ & & $\begin{array}{l}0.0351 \\
(0.0230)\end{array}$ & & $\begin{array}{l}-0.0034 \\
(0.004)\end{array}$ \\
\hline & Use of fertilizer & & $\begin{array}{c}.3867 \\
(1.5188)\end{array}$ & & $\begin{array}{l}0.0341 \\
(0.1120)\end{array}$ & & $\begin{array}{l}-0.0008 \\
(0.0265)\end{array}$ \\
\hline & Use of hired labor & & $\begin{array}{c}1.3970 \\
(2.5120)\end{array}$ & & $\begin{array}{l}0.0322 \\
(0.1310)\end{array}$ & & $\begin{array}{l}-0.0012 \\
\quad(0.0225)\end{array}$ \\
\hline \multirow[t]{2}{*}{ Area dummy } & Yatinuwara & $\begin{array}{r}-0.6058^{* * * *} \\
(1.507)\end{array}$ & $\begin{array}{l}-6.2887^{* * * *} \\
(1.5345)\end{array}$ & $\begin{array}{l}-0.2607 * * \\
(0.0920)\end{array}$ & $\begin{array}{l}-0.3000^{* *} \\
(0.0935)\end{array}$ & $\begin{array}{l}0.0293 \\
(0.0176)\end{array}$ & $\begin{array}{l}0.0309 \\
\quad(0.0198)\end{array}$ \\
\hline & Udunuwara & $\begin{array}{l}-2.7890 \\
(1.970)\end{array}$ & $\begin{array}{l}-3.0675 \\
(1.6931)\end{array}$ & $\begin{array}{l}-0.0973 \\
(0.094)\end{array}$ & $\begin{array}{l}-0.1035 \\
(0.0928)\end{array}$ & $\begin{array}{l}0.0087 \\
(0.0203)\end{array}$ & $\begin{array}{c}0.0079 \\
(0.0199)\end{array}$ \\
\hline R-squared & & 0.2836 & 0.2927 & 0.1900 & 0.1658 & 0.0942 & 0.0884 \\
\hline Number of observations & & 153 & 155 & 155 & 154 & 155 & 154 \\
\hline
\end{tabular}

$* \mathrm{P}<0.05, * * \mathrm{P}<0.01, * * * \mathrm{P}<0.001$. Standard errors are given in the Parenthesis. 
Table 9: $\quad$ Determinants of plant diversity in home-gardens in Kurunegala district (Model 1, 2 and 3).

\begin{tabular}{|c|c|c|c|c|c|c|c|}
\hline \multirow[t]{2}{*}{ Independent Variables } & \multirow[t]{2}{*}{ Unit of Measurement } & \multicolumn{2}{|c|}{$\begin{array}{c}\text { Dependent Variable: Richness } \\
\text { Index (Model 1) }\end{array}$} & \multicolumn{2}{|c|}{$\begin{array}{c}\text { Dependent Variable: Shannon } \\
\text { Index (Model 2) }\end{array}$} & \multicolumn{2}{|c|}{$\begin{array}{c}\text { Dependent Variable: Simpson } \\
\text { Index (Model 3) }\end{array}$} \\
\hline & & $\begin{array}{l}\text { Output Based } \\
\text { Indices }\end{array}$ & $\begin{array}{c}\text { Combined } \\
\text { Indices }\end{array}$ & $\begin{array}{l}\text { Output Based } \\
\text { Indices }\end{array}$ & $\begin{array}{c}\text { Combined } \\
\text { Indices }\end{array}$ & $\begin{array}{l}\text { Output Based } \\
\text { Indices }\end{array}$ & $\begin{array}{l}\text { Combined } \\
\text { Indices }\end{array}$ \\
\hline Household size & Number of people in the household & $\begin{array}{l}0.1066 \\
(.390)\end{array}$ & $\begin{array}{c}0.1107 \\
(0.428)\end{array}$ & $\begin{array}{c}0.0230 \\
(0.035)\end{array}$ & $\begin{array}{c}0.0346 \\
(0.042)\end{array}$ & & $\begin{array}{r}-0.0101 \\
(.009)\end{array}$ \\
\hline Education & Number of years of schooling & & $\begin{array}{c}0.1543 \\
(0.223)\end{array}$ & & $\begin{array}{r}0.0025 \\
(0.018)\end{array}$ & & \\
\hline Labor availability & $\begin{array}{l}\text { Total labor hours available for home-garden } \\
\text { activities per week }\end{array}$ & $\begin{array}{l}0.0869 \\
(.093)\end{array}$ & $\begin{array}{c}0.0660 \\
(0.095)\end{array}$ & $\begin{array}{l}0.0064 \\
(.007)\end{array}$ & $\begin{array}{c}0.0028 \\
(0.008)\end{array}$ & $\begin{array}{l}-0.0010 \\
(0.002)\end{array}$ & \\
\hline Dependency Ratio & Unit less & $\begin{array}{l}-2.2561 \\
(2.618)\end{array}$ & $\begin{array}{l}-2.3846 \\
(2.748)\end{array}$ & $\begin{array}{l}-0.3027 \\
(0.207)\end{array}$ & $\begin{array}{c}-.2303 \\
(0.220)\end{array}$ & $\begin{array}{c}0.0484 \\
(0.047)\end{array}$ & $\begin{array}{c}0.0665 \\
(0.046)\end{array}$ \\
\hline Land Size & Perch & $\begin{array}{l}0.0415^{*} \\
(.0162)\end{array}$ & $\begin{array}{l}0.0247 \\
(0.016)\end{array}$ & $\begin{array}{c}0.0000 \\
(0.001)\end{array}$ & $\begin{array}{r}-.0007 \\
(0.001)\end{array}$ & $\begin{array}{c}0.0001 \\
(0.000)\end{array}$ & $\begin{array}{l}0.0001 \\
(.000)\end{array}$ \\
\hline Land square & Square of land area & $\begin{array}{l}-.0001^{*} \\
(.0000)\end{array}$ & $\begin{array}{l}-.0001 \\
(.000)\end{array}$ & $\begin{array}{l}-1.12 * 10^{-6} \\
(0.000)\end{array}$ & $\begin{array}{l}-1.49 * 10^{-6} \\
(0.000)\end{array}$ & $\begin{array}{l}-4.00 * 10^{-8} \\
(0.000)\end{array}$ & $\begin{array}{r}-3.58^{*} 10^{-8} \\
(0.000)\end{array}$ \\
\hline Regular work & House work (0), Regular work (1) & $\begin{array}{l}2.9022 * \\
(1.269)\end{array}$ & $\begin{array}{c}2.3798 \\
(1.511)\end{array}$ & $\begin{array}{c}0.1283 \\
(0.109)\end{array}$ & $\begin{array}{c}0.0765 \\
(0.130)\end{array}$ & $\begin{array}{c}-0.0219 \\
(0.024)\end{array}$ & $\begin{array}{c}0.0061 \\
(0.024)\end{array}$ \\
\hline Farming & Housework (0), farming (1) & $\begin{array}{l}7.994 * * \\
(2.443)\end{array}$ & $\begin{array}{l}7.0346^{*} \\
(2.729)\end{array}$ & $\begin{array}{l}0.3435^{*} \\
(0.179)\end{array}$ & $\begin{array}{c}0.2866 \\
(0.205)\end{array}$ & $\begin{array}{l}-0.0547 \\
(0.044)\end{array}$ & $\begin{array}{c}-0.0419 \\
(0.043)\end{array}$ \\
\hline Commercial orientation & Percentage of output sold to outside markets & $\begin{array}{l}-9.3082^{* *} \\
(3.216)\end{array}$ & & $\begin{array}{c}-1.2816^{* * * *} \\
(0.258)\end{array}$ & & $\begin{array}{l}0.2772^{* * *} \\
(0.067)\end{array}$ & \\
\hline & Number of products marketed & & $\begin{array}{c}0.6636 \\
(0.524)\end{array}$ & & $\begin{array}{l}-0.0172 \\
(0.036)\end{array}$ & & $\begin{array}{l}-0.0008 \\
(0.006)\end{array}$ \\
\hline & Use of fertilizer & & $\begin{array}{l}-0.7114 \\
(1.343)\end{array}$ & & $\begin{array}{c}0.0419 \\
(0.108)\end{array}$ & & $\begin{array}{l}-0.006 \\
(0.019)\end{array}$ \\
\hline & Use of hired labor & & $\begin{array}{c}-1.3986 \\
(2.209)\end{array}$ & & $\begin{array}{l}-0.063 \\
(0.161)\end{array}$ & & $\begin{array}{l}-0.0034 \\
(0.023)\end{array}$ \\
\hline Area dummy & Pannila & $\begin{array}{l}2.3736 \\
(1.650)\end{array}$ & $\begin{array}{l}-3.6001^{*} \\
(1.734)\end{array}$ & $-0.0289(0.131)$ & $\begin{array}{c}0.0738 \\
(0.142)\end{array}$ & $\begin{array}{c}0.0391 \\
(0.030)\end{array}$ & $\begin{array}{c}0.0048 \\
(0.026)\end{array}$ \\
\hline & Ridigama & $\begin{array}{l}-0.4404 \\
(1.504)\end{array}$ & $\begin{array}{c}1.4029 \\
(1.768)\end{array}$ & $\begin{array}{l}-0.2746^{*} \\
(0.128)\end{array}$ & $\begin{array}{l}-0.5113 \\
(0.153)\end{array}$ & $\begin{array}{c}0.0628 \\
(0.030)\end{array}$ & $\begin{array}{c}0.0124 \\
(0.028)\end{array}$ \\
\hline R-squared & & 0.2307 & 0.2211 & 0.2357 & 0.1064 & 0.1771 & 0.0935 \\
\hline Number of observations & & 158 & 149 & 158 & 149 & 158 & 208 \\
\hline
\end{tabular}

$* \mathrm{P}<0.05, * * \mathrm{P}<0.01, * * * \mathrm{P}<0.001$. Standard errors are given in the Parenthesis. 


\section{References}

Abdoellah, O.S., H.Y Hadikusumah, K. Takeuchi and S. Okubo (2006). Commercialization of Homegardens in an Indonesian Village: Vegetation Composition and Functional Changes. Agroforestry systems, 68: 1-13.

Abdoellah, O.S., B.G. Parikesit, and H.Y. Hadikusumah (2002). Homegardens in the Upper Citarum Watershed, West Java: A Challenge for in Situ Conservation of Plant Genetic Resources1. Home gardens and in situ conservation of plant genetic resources in farming systems, 140.

Abebe, T. (2005). Diversity in Homegarden Agroforestry Systems of Southern Ethiopia. Wageningen University and Research Centre.

Ariyadasa, K.P. (2002). Assessment of the Tee Resources in the Homegarden of Sri Lanka. FAO Regional Office for Asia and the Pacific, Thailand.

Balint, B.E. (2003). Determinants of Commercial Orientation and Sustainability of Agricultural Production of the Individual Farms in Romania. PhD. University of Bonn. Viewed on 25.06.2010, $\langle$ http://www.pasad.uni-bonn.de/proposal_balint.pdf>.

Ban, N. and O.T. Coomes (2004). Home Gardens in Amazonian Peru: Diversity and Exchange of Planting Material. Geographical Review, 94: 348-367.

Bernholt, H., K. Kehlenbeck, J. Gebauer and A. Buerkert (2009). Plant Species Richness and Diversity in Urban and Peri-urban Gardens of Niamey, Niger. Agroforestry Systems, 77: 59-179.

Candian Forest Product Ltd. (2003). Monitoring Plant Diversity: Simpson's Index and Species Richness Assessment, Prince George, British Colombia.

Department of Census and Statistics (2002). Census of Agriculture, Department of Census and Statistics, Sri Lanka. http://www.statistics.gov.lk/agriculture/Small\%20holding\%20sector/index.ht m.

FAO (2010). Improving Nutrition through Home Gardening. <http://www.fao.org/ag/agn/nutrition/household_gardens_en.stm>. 
Hoogerbrugge, I.D. and L.O. Fresco (1993). Homegarden Systems: Agricultural Characteristics and Challenges. Gatekeeper Series, 39.

Gajaseni, J. and N. Gajaseni (1999). Ecological Rationalities of the Traditional Homegarden System in the Chao Phraya Basin, Thailand. Agroforestry Systems, 46: 3-23.

Jacob, V. and W. Alles (1987). Kandyan Gardens of Sri Lanka. Agroforestry Systems, 5: 123-137.

Kabir, M.E. and E.L. Webb (2009). Household and Homegarden Characteristics in Southwestern Bangladesh. Agroforestry Systems, 75: 129-145.

Kehlenbeck, K., H.S. Arifin and B.L. Maass (2007).Plant Diversity in Homegardens in a Socio-Economic and Agro-ecological Context, Environmental Science and Engineering, Stability of Tropical Rainforest Margins. Germany: Springer Berlin Heidelberg Publishers.

Kehlenbeck, K. and B.L. Maass (2004). Crop Diversity and Classification of Homegardens in Central Sulawesi, Indonesia. Agroforestry System, 63: 52-62.

Kodithuwakku, S.S. and P. Rosa (2002). The Entrepreneurial Success in a Constrained Environment. Journal of Business Venturing (Special Issue on Qualitative Research in Entrepreneurship), 17(5): 431-465.

Kumari M.A.S. (2009). Plant Diversity in Homegardens and its Contribution to Household Economy in Suburban Areas in Sri Lanka. M.Sc. Dissertation, University of Mahidol. Thailand.

Lerch, N.C. (1999). Homegardens, Cultivated Plant Diversity, and Exchange of Planting Material in the Pacaya-Samiria National Reserve Area, Northeastern Peruvian Amazon. McGill University.

Major, J., C.R. Clement and A. Ditommaso (2005). Influence of Market Orientation on Food Plant Diversity of Farms Located on Amazonian Dark Earth in the Region of Manaus, Amazonas. Brazil. Economic Botany, 59: 77-86.

Mmom, P.C. (2009). Impact of Poverty and Changing Cropping Systems on Agro-crop Diversity in the upper Niger Delta, Nigeria. IAIA09 Conference Proceedings', Impact Assessment and Human Well-Being 
$29^{\text {th }}$ Annual Conference of the International Association for Impact Assessment.

Ministry of Agricultural Development and Agrarian Services, 2010. National Agricultural Policy. $\quad$ Viewed <http://www.mimrd.gov.lk/download.php?c=1>.

Olszewski, T.D. (2004). A Unified Mathematical Framework for the Measurement of Richness and Evenness within and among Multiple Communities. Oikos, 104(2): 377-387.

Pandey, C.B., K. Lata, A. Venkatesh and R.P. Medhi (2006). Diversity and Species Structure of Homegardens in South Andaman. Tropical Ecology, 47: 251-258.

Perera, A.H. and R. Rajapakse (1991). A Baseline Study of Kandyan Forest Gardens of Sri Lanka: Structure, Composition and Utilization. Forest Ecology and Management, 45: 269-280.

Perrault-Archambault, M. and O.T. Coomes (2008). Distribution of Agrobiodiversity in Homegardens along the Corrientes River, Peruvian Amazon. Economic Botany, 62: 109-126.

Pushpakumara, D., A. Wijesekara and D. Hunter (2010). Kandyan Homegardens: A Promising Land Management System in Sri Lanka. Sustainable use of biological di-versity in socio-ecological production landscapes, 102.

Soemarwoto, O. (1987). Homegardens: A Traditional Agroforestry System with a Promising Future. In Agroforestry: A decade of Development, Steppler, H.A. and Nair, P.K.R. (eds.). Nairobi, Kenya International Council for Research in Agroforestry.

Soemarwoto, O. and G.R. Conway (1992). The Javanese Homegarden. $J$. Farm. Syst. Res. Extens., 2: 95-118.

Torquebiau, E. (1992). Are Tropical Agroforestry Homegardens Sustainable? Agriculture, Ecosystems \& Environment, 41: 189-207.

Weerahewa J., G. Pushpakumara, P. Silva, C. Daulagala, R. Punyawardena, S. Premalal, G. Miah, J. Roy, S. Jana, and B. Marambe (2012): Are Homegarden Ecosystems Resilient to Climate Change? An Analysis 
of the Adaptation Strategies of Homegardeners in Sri Lanka. APN Science Bulletin 2: 22-27.

Wickramasinghe, A. (1995). Homegardens: Habitations Rescuing Biodiversity. MPTS News 4, 1-4.

Wiehle, M., S. Goenster, K. Kehlenbeck, J. Gebauer and A. Mohamed (2011). Socio-economic Factors and Garden Size Affect Plant Species Richness and Diversity of Homegardens of Nuba Mountains, Sudan, Proceedings of the 2001 Conference, Bonn University, Development on the Margin, Germany.

Winters, P., R. Cavatassi and L. Lipper (2006). Sowing the Seeds of Social Relations: The Role of Social Capital in Crop Diversity. ESA Working Paper No. 06-16.

Yue, T.X., J.Y. Liu, Y. Liu, S.Q. Chen, Z.Q. Li, Y.Z. Tian and Feng Ge (2004). Diversity Indices and Spatial Scales Greatly Effect the Conclusions of Relationship between Biodiversity and Ecosystem Functions. Paper presented at Bridging Scales and Epistemologies: Linking local knowledge and Global Science in multi-scale assessment, Alexandria, Egypt. 


\section{Annexure}

Scientific names of the crops mentioned in the paper

\begin{tabular}{|c|c|c|}
\hline Local Name & English Name & Botanical Name \\
\hline Alipera & Avocado & PerseaamericanaMiller \\
\hline$A m b a$ & Mango & Mangiferaindica L. \\
\hline Annasi & Pine apple & Ananascomosus(L.) Merr. \\
\hline Anoda & Anona & Annonamuricata $L$. \\
\hline Bandakka & Okra & Abelmoschusesculentus(L.) Moench \\
\hline Cocoa & Cocoa & Theobroma cacao L. \\
\hline Dehi & Lime & $\begin{array}{l}\text { Citrus aurantifolia(Christm. \& } \\
\text { Panzer) Swingle }\end{array}$ \\
\hline Dodan & Orange & Citrus aurantium L. \\
\hline Inguru & Ginger & Zingiberofficinale Rosc. \\
\hline adju & Cashew & Anacardiumoccidentale L. \\
\hline Karabuneti & Clove & $\begin{array}{l}\text { Syzygiumaromaticum(L.) Merr. \& } \\
\text { Perry }\end{array}$ \\
\hline Kesel & Banana & Musa sapientum L. \\
\hline Kiriala & & Sonneratia alba J. Sm. \\
\hline Kochchi & Chilli & Capsicum frutescens $L$. \\
\hline Kopi & Coffee & Coffeaarabica $L$. \\
\hline Kos & Jack & ArtocarpusheterophyllusLam. \\
\hline Murunga & Drumstics & Moringaoleifera Lam. \\
\hline Nivithi & Spinach & Basella alba $L$. \\
\hline Papol & Papaw & Carica papaya $L$. \\
\hline Pepper & Gammiris & Piper nigrum L. \\
\hline Pera & Guava & PsidiumguajavaL. \\
\hline Pol & Coconut & CocosnuciferaL. \\
\hline Puwak & Areca nut & Areca catechu L. \\
\hline Sadikka & Nutmeg & MyristicafragransHoutt. \\
\hline Sadikka & Nutmeg & MyristicafragransHoutt. \\
\hline Thembili & Kingcoconut & Cocosnucifera \\
\hline Wambatu & Brinjal & Solanum melongena $L$. \\
\hline
\end{tabular}

